\title{
ASSOCIATION BETWEEN RANKL [RS9594759] AND IL10 [RS1800896] GENES POLYMORPHISM AND DECIDUOUS TOOTH ERUPTION TERMS IN UKRAINIANS BORN MACROSOMIC
}

DOI: 10.36740/WLek202002126

\author{
Olga V. Garmash ${ }^{1}$, Zoia I. Rossokha ${ }^{2}$, Nataliya G. Gorovenko ${ }^{3}$ \\ 'KHARKIV NATIONAL MEDICAL UNIVERSITY, KHARKIV, UKRAINE \\ 2REFERENCE CENTER FOR MOLECULAR DIAGNOSTICS OF THE MINISTRY OF HEALTH OF UKRAINE, KYIV, UKRAINE \\ ${ }^{3}$ SHUPYK NATIONAL MEDICAL ACADEMY OF POSTGRADUATE EDUCATION OF THE MINISTRY OF HEALTH OF UKRAINE, KYIV, UKRAINE
}

\begin{abstract}
The aim: The article deals with analyzing the influence of polymorphic variants of CYP19A1 [rs2414096, rs936306], ESR1 [rs2234693, rs9340799], IL1 [rs1143627], IL6 [rs1800796], IL10 [rs1800896] and RANKL [r5959389] genes on deciduous tooth eruption terms in individuals born macrosomic.

Materials and methods: 171 individuals participated in the multi-stage study (144 macosomic-at-birth individuals and 27 normosomic-at-birth persons). This study included only persons who have preserved information about the timing of deciduous tooth eruption - 159 persons (aged from 4 to 55 years), male and female (male / female ratio was $1.5 / 1$ ). Results and conclusions: The presence of the $G$ allele in CYP19A1 [rs2414096] gene and the -351 A allele in ESR1 [rs9340799] gene were found to be risk factors for fetal macrosomia formation. The research revealed an association of RANKL [rs9594759] gene variants which is a multiplicative model of inheritance and IL-10 [rs1800896], an overdominant model of inheritance, with an increased risk of tooth delay. Besides the variants of RANKL [rs9594759] and IL-10 [rs1800896] genes a multidirectional modifying effect on the timing of tooth eruption in macrosomic-at-birth individuals made the variant of CYP19A1 [rs2414096] gene - a significant dominant and over-dominant model of inheritance. Further analysis of intergenic interactions will facilitate the application of the obtained results in clinical practice by creating a molecular profile of individuals with deviations in the tooth eruption timing.
\end{abstract}

KEY WORDS: fetal macrosomia, deciduous teeth, CYP19A1 [rs2414096], ESR1 [rs9340799], IL-10 [rs1800896], RANKL: C> T [rs9594759] genes polymorphism

Wiad Lek. 2020;73(2):342-351

\section{INTRODUCTION}

The fetal macrosomia (birth weight is greater than or equal to $4,000 \mathrm{~g}[1])$ is known to have long-term effects such as premature or delayed deciduous tooth eruption. The reasons for these deviations have not yet been explained. The problem of the timing of deciduous tooth eruption is still an open topic. A wide range of endogenous and exogenous factors, including maternal and paternal factors [2], child's ethnic group, breastfeeding or artificial feeding [3], parental eating habits [4], and even regional features have an impact on the timing of eruption [5].

The scientific literature distinguishes between biological and chronological delay of tooth eruption. Biological delay of tooth eruption is recorded when the eruption of the teeth did not occur in the presence of $2 / 3$ or more of the formed tooth root. The degree of the tooth root system formation is determined by radiological examination. A chronological delay of deciduous tooth considered to be an eruption that occurred later than $2 \mathrm{xSD}$ from the regional norms of tooth eruption [6]. Conversely, a chronologically premature eruption is considered to be a situation where the period of tooth eruption is less than the regional norm by two or more standard deviations. Using the principle of two standard deviations from the median value of the number of teeth in children of the Kharkiv population, if the eruption of the first tooth occurred at the age of 4 months or earlier, premature eruption of teeth was recorded, and if it happened at 11 months or later it was recorded as a delay of eruption [7].

Diametrically opposite is the information on the effect of large birth weight (fetal macrosomia) on the terms of teeth eruption. A number of scientists have cited evidence that the greater the body weight of a newborn baby, the faster the baby's first tooth will appear, and the more deciduous teeth will be by the age of 1 or 2 years [8]. The same study linked the length of a newborn baby's body to the speed of eruption and tooth growth in infants, and concluded that the longer the length of the newborns body is, the faster the first tooth erupts. They are motivated by the fact that the greater length of the body indicates a greater "formation" of the skeleton [8]. Other researchers also believe that the shorter the child's length is, the later his/her deciduous teeth will appear and the later deciduous teeth will be replaced with permanent $[9,10]$. At the same time, there are studies that deny such dependence. Khuraseva A. B. [11] writes that children whose birth weight values exceeded 
90 centile levels, on the contrary, have a delayed deciduous tooth eruption.

Our previous retrospective-statistical [12] and clinical [13] studies showed that the rate of teeth eruption did not depend on the length of the body or body weight at birth, but rather height-weight index at birth, in children born macrosomic during the first year of life. In most cases, delayed tooth eruption had children who were long and relatively thin at birth, i. e. our findings do not match the data reported in [9]. Children (girls) who had a large body length and high birth height-weight index had premature teeth eruption [7]. Early eruption is associated with low tooth mineralization [9] and is often combined with the occurrence of carious lesions in deciduous and even permanent [14] teeth. The latter relates directly to children born macrosomic [15]. The results we have previously obtained are sufficiently reliable, but not all clinical cases of impaired terms of teeth eruption fit into the proposed scheme.

According to the latest information [16], deviation from the physiological timing of both deciduous and permanent teeth eruption creates the preconditions for the development of periodontal tissue diseases in ontogeny. The timing of teeth eruption depends on the features of the genetic processes that control the processes of bone formation and growth, as well as maintaining optimal metabolic processes in it, despite numerous exogenous factors [16].

When selecting the optimal candidate genes, after analyzing the literature, it was planned to study the variants of CYP19A1, ESR1, IL1, IL6, IL10 and RANKL genes, which are expressed in fetal tissues, and interact to regulate bone growth, mineralization of the tooh germs.

The CYP19A1 gene encodes an aromatase enzyme. Aromatase functioning from the intrauterine period, in the cell it is in the endoplasmic reticulum and is responsible for protein biosynthesis, in particular, during the processing and transporting stages. This enzyme converts androgens to various forms of estrogen, which plays a role in regulating bone growth in individuals of both sexes in childhood $[17,18]$ and adulthood $[19,20]$.

Estrogens regulate bone growth, and polymorphic variants of the ESR1 (estrogen receptor 1) gene, altering the transcriptional activity of the gene, they increase the risk of estrogen-dependent diseases, and osteoporosis in the first instance. Variants of this gene are associated with bone mineralization in man [21]. As reported in our previous study, they also affect the anlage and mineralization of deciduous teeth, which demonstrated the association of the CYP19A1 [rs 2414096] gene variant with the early development of childhood caries in individuals born macrosomic [22].

RANKL (Receptor Activator of Nuclear Factor Kappa-B Ligand) is a membrane protein, a cytokine of a tumor necrosis factor family. It plays an important role in bone metabolism by activating osteoclasts. Variants of this gene are responsible for the occurrence of type 2 autosomal recessive osteopetrosis [23], variants of this gene at points rs9594759 and rs9594738 are also responsible for bone disorder characterized by increased density due to delayed resorption of immature tissue [24].

Support for bone homeostasis also occurs with the involvement of many cytokines. Along with other cytokines, IL1 b (Interleukin 1b) and IL6 (Interleukin 6) take part in the production of osteolcasts, and IL10 (Interleukin 10), in particular, belongs to anti-osteocalastogen cytokines. Generally, this problem is outlined in [25]. IL10 is a protein encoded by the gene with the same name, is a cytokine that influences immunoregulation and is responsible for the «suppression» of the inflammatory process. It participates in the inhibition of proinflammatory cytokines production, in particular IL1 b and IL6. IL1b is a protein encoded by the gene of the same name is a proinflammatory cytokine, regulates acute and chronic inflammation, and is involved in bone resorption [26]. The IL6 gene encodes a protein that mediates the acute phase of inflammation and plays a central role in the pathogenesis of osteoporosis with increased bone resorption. Alternative results were obtained by the authors [27], who showed that IL6 behaved differently depending on the level of RANKL. Zhao Wang and co-authors wrote about the unstable association of variant IL-6 gene polymorphisms, in particular IL-6 -174 G/C with bone mineral density [28]. There is evidence that overproduction of IL-6 may contribute to the development of disease during aging [29]. Estrogens and androgens are known to suppress the action of IL-6 [30].

\section{THE AIM}

The purpose of this study was to investigate the association between polymorphic variants of CYP19A1 [rs2414096, rs936306], ESR1 [rs2234693, rs9340799], IL1 [rs1143627], IL6 [rs1800796], IL10 [rs1800896], and [rs9594738, rs 9594759] genes and disturbance in tooth eruption time (premature or delayed eruption) in individuals born macrosomic.

\section{MATERIALS AND METHODS}

In total, 171 individuals participated in the multi-stage study (144 macosomic-at-birth individuals and 27 normosomic-at-birth persons). This study included only persons who have preserved information about the timing of deciduous tooth eruption - 159 persons (aged from 4 to 55 years), male and female (male / female ratio was 1.5 / 1) living in Kharkiv and surrounding areas of Ukraine. Exclusion criteria: gestational age at birth of less than 37 or greater than 42 weeks; birth weight $2700 \mathrm{~g}$ or less; the presence of developmental disabilities and developmental anomalies; the presence of systemic diseases or pathological conditions that can affect bone metabolism, the presence of other diseases in the decompensation stage; lack of information on weight-height parameters at birth and timing of deciduous tooth eruption. The criteria for inclusion in the Main Study Group were: consent to participate in the study; age from 4 to 55 years; birth weight more than or equal to $4000 \mathrm{~g}$; premature or delayed eruption of deciduous teeth and the absence of the above exclusion criteria. 
Table 1. Data on weight-height parameters at birth in study participants.

\begin{tabular}{cccc}
\hline Category of an individual & Weight at birth, $\mathbf{~ k g}$ & Body length at birth, $\mathbf{c m}$ & Height-weight index at birth, $\mathbf{~ g g} / \mathbf{m}^{\mathbf{3}}$ \\
\hline Macrosomic-at-birth & $4,28 \pm 0,04$ & $55,10 \pm 0,44$ & $25,87 \pm 0,62$ \\
\hline Normosomic-at-birth & $3,35 \pm 0,10$ & $51,96 \pm 0,71$ & $24,03 \pm 1,12$ \\
\hline
\end{tabular}

Table 2. The mode of amplification and detection of Real-time PCR products with the «Osteoporosis»set.

\begin{tabular}{|c|c|c|c|c|c|c|c|}
\hline $\begin{array}{l}\text { Block } \\
\text { number }\end{array}$ & Temperature, ${ }^{\circ} \mathrm{C}$ & Minutes & Seconds & $\begin{array}{c}\text { Number of } \\
\text { cycles }\end{array}$ & $\begin{array}{l}\text { Regime of optical } \\
\text { measuring }\end{array}$ & $\Delta t,{ }^{\circ} \mathrm{C}$ & Block type \\
\hline \multirow[t]{2}{*}{1} & 80.0 & 02 & 00 & \multirow{2}{*}{1} & & & \multirow{2}{*}{ Cycle } \\
\hline & 94.0 & 05 & 00 & & & & \\
\hline \multirow{2}{*}{2} & 94.0 & 00 & 30 & \multirow{2}{*}{5} & & & \multirow{2}{*}{ Cycle } \\
\hline & 67.0 & 00 & 15 & & $\sqrt{ }$ & & \\
\hline \multirow{2}{*}{3} & 94.0 & 00 & 05 & \multirow{2}{*}{45} & & & \multirow{2}{*}{ Cycle } \\
\hline & 67.0 & 00 & 15 & & $\sqrt{ }$ & & \\
\hline 4 & 25.0 & 00 & 30 & 1 & & & Cycle \\
\hline 5 & 25.0 & 00 & 15 & 50 & $\sqrt{ }$ & $1,0^{\circ} \mathrm{C}$ & $\begin{array}{c}\text { "melting curve", } \\
\Delta \mathrm{t}=1^{\circ} \mathrm{C} ; \\
\mathrm{T}_{\text {кон }}=75^{\circ} \mathrm{C}\end{array}$ \\
\hline 6 & 10.0 & & & save & & & Save \\
\hline
\end{tabular}

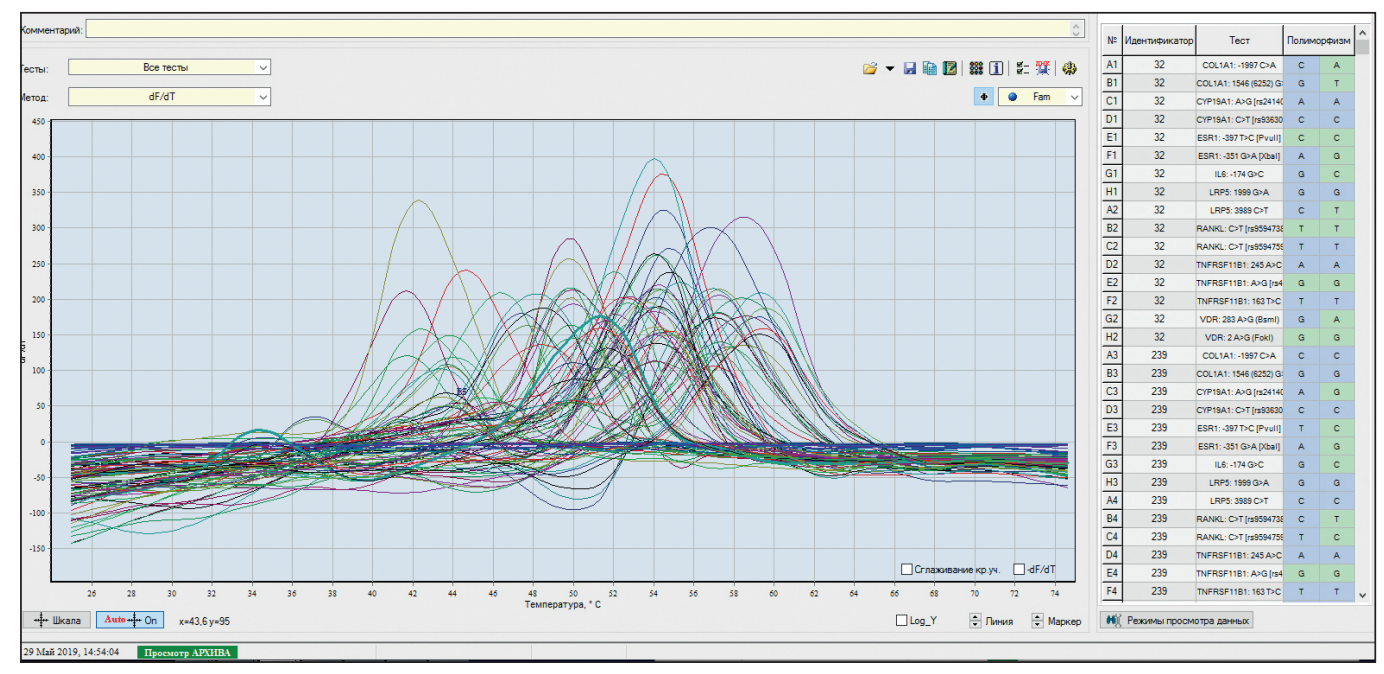

Figure 1. Graph of dependence of genomic DNA fluorescence on the melting point of the samples (set «Osteoporosis», «DNA technology»).
The main group with premature eruption (MGPE) consisted of 16 people (macrosomic-at-birth) who had premature eruption of deciduous teeth (PEDT). The main group with a delayed eruption (MGDE) consisted of 25 individuals (macrosomic-at-birth) who had a delayed eruption of deciduous teeth (DEDT). The comparison group I (CG I), 97 individuals (macrosomic-at-birth) included those who had neither premature eruption nor delay of deciduous teeth eruption. Comparison Group II (CG II) involved 21 individuals who were born with normal weight-height parameters (normosomic) and had neither premature nor delayed eruption of deciduous teeth.

All participants of the study, or their parents, in the case of a minor child, gave their writing concent for participation in this study. The Ethics and Bioethics Committee of Kharkiv National Medical University (Minutes No. 5 of May 10,2016) confirmed that the techniques used in this study were applied within human rights norms according to the current Ukrainian law, complied with the international ethical standards and did not violate ethical standards. norms in science and standards for biomedical research.

Data on weight-height parameters at birth (Table 1) and on the timing of tooth eruption in study participants were obtained from child development records, inpatient medical records, or other documentation stored in medical archives or in study participants. The mean age of macrosomic at birth individuals was $21.2 \pm 2.3$ years and the mean age of normosomic-at-birth individuals was $21.6 \pm 5.6$ years. At the time of inclusion in the study, all participants, according to doctors of other specialists, had no associated concomitant pathology and their body mass index was in the range between 18.5 and $30 \mathrm{~kg} / \mathrm{m}^{2}$, that is, they had neither a body weight deficit nor obesity. 
Table 3. Frequencies of genotype distribution for different groups of study participants.

\begin{tabular}{|c|c|c|c|c|c|c|c|c|c|}
\hline \multirow{2}{*}{ Gene } & \multirow{2}{*}{ Genotypes } & \multicolumn{2}{|c|}{ MGPE } & \multicolumn{2}{|c|}{ MGDE } & \multicolumn{2}{|c|}{ CGI } & \multicolumn{2}{|c|}{ CGII } \\
\hline & & $\mathbf{n}$ & $\%$ & $\mathbf{n}$ & $\%$ & $\mathbf{n}$ & $\%$ & $\mathbf{n}$ & $\%$ \\
\hline \multirow{3}{*}{ CYP19A1: A>G [rs2414096] } & AA & 3 & 18.75 & 7 & 29.17 & 22 & 22.45 & 11 & 52.38 \\
\hline & AG & 12 & 75.00 & 9 & 37.50 & 48 & 48.98 & 8 & 38.10 \\
\hline & GG & 1 & 6.25 & 8 & 33.33 & 28 & 28.57 & 2 & 9.52 \\
\hline \multirow{3}{*}{ CYP19A1: C>T [rs936306] } & $\mathrm{CC}$ & 16 & 100.00 & 17 & 70.83 & 68 & 70.10 & 17 & 80.95 \\
\hline & CT & 0 & 0.00 & 6 & 25.00 & 27 & 27.84 & 4 & 19.05 \\
\hline & $\mathrm{TT}$ & 0 & 0.00 & 1 & 4.17 & 2 & 2.06 & 0 & 0.00 \\
\hline \multirow{3}{*}{$\begin{array}{c}\text { ESR1: }-397 \text { T>C [Pvull] } \\
\text { [rs2234693)] }\end{array}$} & $\mathrm{TT}$ & 4 & 25.00 & 5 & 21.73 & 27 & 28.42 & 3 & 14.29 \\
\hline & $\mathrm{CT}$ & 9 & 56.25 & 16 & 69.57 & 45 & 47.37 & 12 & 57.14 \\
\hline & $\mathrm{CC}$ & 3 & 18.75 & 2 & 8.70 & 23 & 24.21 & 6 & 28.57 \\
\hline \multirow{3}{*}{$\begin{array}{c}\text { ESR1: }-351 \mathrm{G}>\mathrm{A}[\mathrm{Xbal}] \\
{[\mathrm{rs} 9340799]}\end{array}$} & GG & 1 & 6.25 & 1 & 4.35 & 9 & 9.68 & 4 & 20.00 \\
\hline & AG & 11 & 68.75 & 13 & 56.52 & 46 & 49.46 & 13 & 65.00 \\
\hline & $\mathrm{AA}$ & 4 & 25.00 & 9 & 39.13 & 38 & 40.86 & 3 & 15.00 \\
\hline \multirow{3}{*}{ IL6: -174 G>C[rs1800796] } & GG & 7 & 43.75 & 6 & 25.00 & 32 & 32.65 & 6 & 28.57 \\
\hline & CG & 9 & 56.25 & 11 & 45.83 & 45 & 45.92 & 11 & 52.38 \\
\hline & $\mathrm{CC}$ & 0 & 0.00 & 7 & 29.17 & 21 & 21.43 & 4 & 19.05 \\
\hline \multirow{3}{*}{ RANKL: C>T [rs9594738] } & $\mathrm{CC}$ & 6 & 37.50 & 5 & 20.83 & 36 & 36.73 & 6 & 28.57 \\
\hline & $\mathrm{CT}$ & 8 & 50.00 & 10 & 41.67 & 36 & 36.73 & 10 & 47.62 \\
\hline & $\mathrm{TT}$ & 2 & 12.50 & 9 & 37.50 & 26 & 26.54 & 5 & 23.81 \\
\hline \multirow{3}{*}{ RANKL: C>T [rs9594759] } & $\mathrm{CC}$ & 4 & 25.00 & 4 & 16.00 & 33 & 34.02 & 6 & 28.57 \\
\hline & $\mathrm{CT}$ & 10 & 62.50 & 9 & 36.00 & 39 & 40.21 & 6 & 28.57 \\
\hline & $\mathrm{TT}$ & 2 & 12.50 & 12 & 48.00 & 25 & 25.77 & 9 & 42.86 \\
\hline \multirow{3}{*}{$\begin{array}{l}\text { IL1b: }-31 \mathrm{~T}>\mathrm{C} \\
\text { [rs1143627] }\end{array}$} & TT & 6 & 42.86 & 9 & 40.91 & 37 & 41.58 & 10 & 50.00 \\
\hline & $\mathrm{TC}$ & 5 & 35.71 & 10 & 45.45 & 34 & 38.20 & 9 & 45.00 \\
\hline & $\mathrm{CC}$ & 3 & 21.43 & 3 & 13.64 & 18 & 20.22 & 1 & 5.00 \\
\hline \multirow{3}{*}{$\begin{array}{c}\text { IL10: }-1082 \\
\text { G>A [rs1800896] }\end{array}$} & GG & 5 & 33.33 & 11 & 52.38 & 31 & 34.83 & 5 & 25.00 \\
\hline & GA & 9 & 60.00 & 6 & 28.57 & 44 & $\begin{array}{l}49.44 \\
1573\end{array}$ & 14 & 70.00 \\
\hline & $A A$ & 1 & 6.67 & 4 & 19.05 & 14 & 15.73 & 1 & 5.00 \\
\hline
\end{tabular}

Molecular genetic research consisted of several steps: material collection; isolation of nucleic acids from biological material; amplification and data analysis. Buccal epithelial cell scrapings were used as the material for molecular genetic testing of candidate genes. The scrapings were collected using a disposable sterile probe from the inner surface of the cheek, transferring to a $0.5 \mathrm{ml}$ sterile saline tube. After that, following the requirements of the cold chain, they were transported to the medical laboratory "Analytics». The scrapings of epithelial cells were immediately worked on, DNA extraction was performed.

DNA extraction was carried out by the «Proba-NK» set produced by the Scientific Production Association «DNA Technology» according to the manufacturer's recommendations. Polymerase chain reaction (PCR) was used to analyze gene polymorphism with real-time results recording using the «Osteoporosis» set of the «DNA Technology». The amplification reaction was performed according to the manufacturer's requirements in the "DNA Technology" Devices: DTLight and DT-96 amplifiers (Table 2). Signal registration (Table 2) and interpretation of the fluorescence results of the amplified genomic DNA fragments were performed automatically by the amplifier according to the fluorescence signal accumulation curves (Fig. 1). Molecu- lar-genetic analysis of polymorphic variants IL1b (T-31C) [rs1143627] and IL10 (G-1082A) [rs1800896] genes was performed in a similar manner using the «Litekh» SNPEXPRESS-RV reagents.

The statistical data processing was performed with MS Excel 2016 (license number K9366093I 2016) and STATISTICA 13 (trial software, retrieved from the URL http:// statsoft.ru/products/trial/ on June 18, 2019). Genotype frequencies for each variant of genes were checked for Hardy-Weinberg equilibrium by the criterion $\chi 2$ at $p>0.05$ (https://www.icalculator.info/health/hardy-weinberg-equilibrium-for-two-lleles-calculator.html). The choice of the best model of inheritance was conditioned by a comparison of $\chi^{2}$ and the odds ratio OR.

\section{RESULTS AND DISCUSSION}

Before initiating case-control comparisons and analyzing the obtained results, genotype distributions for CYP19A1, ESR1, IL1 b, IL6, IL10, and RANKL genes were evaluated in the selected comparison groups and according to Hardy-Weinberg equilibrium (Table 3 ).

The following table 4 shows the significant differences when comparing these groups. Among individuals with CG I, the prevalence of AG and GG genotypes by CYP19A1 
Table 4. Comparison of genotype distribution frequencies between CG I and CG II.

\begin{tabular}{|c|c|c|c|c|c|}
\hline \multirow{2}{*}{ Gene } & \multirow{2}{*}{ Genotypes } & \multicolumn{4}{|c|}{ Results of statistical analysis } \\
\hline & & $\mathrm{X}^{2}$ (with Yates correction) & OR & $95 \% \mathrm{Cl}$ & $\mathbf{P}$ \\
\hline \multirow{14}{*}{$\begin{array}{c}\text { CYP19A1: A>G } \\
\text { [rs2414096] }\end{array}$} & \multicolumn{5}{|c|}{ Additive model } \\
\hline & AA & & 0.263 & $0.099-0.701$ & \multirow{3}{*}{0.037} \\
\hline & AG & 6.586 & 1.560 & $0.594-4.098$ & \\
\hline & GG & & 3.800 & $0.830-17.401$ & \\
\hline & \multicolumn{5}{|c|}{ Recessive model } \\
\hline & $\begin{array}{c}A A+A G \\
G G\end{array}$ & 2.394 & $\begin{array}{l}0.263 \\
3.800\end{array}$ & $\begin{array}{c}0.057-1.205 \\
0.830-17.401\end{array}$ & 0.122 \\
\hline & \multicolumn{5}{|c|}{ Dominant model } \\
\hline & $\mathrm{AA}$ & 6310 & 0.263 & $0.099-0.701$ & \multirow{2}{*}{0.012} \\
\hline & $A G+G G$ & 0.510 & 3.800 & $1.428-10.115$ & \\
\hline & \multicolumn{5}{|c|}{ Over-dominant model } \\
\hline & $\mathrm{AA}+\mathrm{GG}$ & 0.444 & 0.641 & 0.244-1.684 & 0.505 \\
\hline & \multicolumn{5}{|c|}{ Multiplicative model } \\
\hline & $A$ & & 0.354 & $0.171-0.731$ & \multirow{2}{*}{0.004} \\
\hline & G & 8.303 & 2.826 & $1.368-5.840$ & \\
\hline \multirow{16}{*}{$\begin{array}{c}\text { ESR1: }-351 \mathrm{G}>\mathrm{A} \text { [Xbal] } \\
\text { [rs9340799] }\end{array}$} & \multicolumn{5}{|c|}{ Additive model } \\
\hline & GG & & 0.429 & $0.118-1.562$ & \multirow{3}{*}{0.164} \\
\hline & GA & 3.615 & 0.527 & $0.193-1.439$ & \\
\hline & AA & & 3.915 & $1.072-14.297$ & \\
\hline & \multicolumn{5}{|c|}{ Recessive model } \\
\hline & $\mathrm{GG}+\mathrm{GA}$ & 3700 & 0.255 & $0.070-0.933$ & \multirow{2}{*}{0.054} \\
\hline & $\mathrm{AA}$ & 3.109 & 3.915 & 1.072-14.297 & \\
\hline & \multicolumn{5}{|c|}{ Dominant model } \\
\hline & GG & 0858 & 0.429 & $0.118-1.562$ & \multirow{2}{*}{0.354} \\
\hline & $\mathrm{GA}+\mathrm{AA}$ & 0.858 & 2.333 & $0.640-8.506$ & \\
\hline & \multicolumn{5}{|c|}{ Over-dominant model } \\
\hline & $G G+A A$ & 1031 & 1.898 & $0.695-5.183$ & \multirow{2}{*}{0.310} \\
\hline & GA & 1.031 & 0.527 & $0.193-1.439$ & \\
\hline & \multicolumn{5}{|c|}{ Multiplicative model } \\
\hline & G & 4592 & 0.475 & $0.238-0.947$ & 0032 \\
\hline & $A$ & 4.592 & 2.107 & $1.056-4.202$ & 0.032 \\
\hline
\end{tabular}

[rs2414096] gene was significantly increased, unlike CG II, and additive, dominant, and multiplicative models of inheritance were the most significant among calculations of risk models. Significant differences were also found for the polymorphic variant of the ESR1 gene (-351 G> A) [rs9340799], and multiplicative and recessive risk model, the best predictive value of which was different. Therefore, the presence of the G allele in the CYP19A1 gene and the presence of the allele -351 A in the ESR1 gene are risk factors for the fetal macrosomia formation, when the tooth eruption timing is kept within normal limits (table 4). Taking into account the significant differences between comparison groups found in the subsequent analysis, we compared the results obtained for the main groups' participants (with altered terms of tooth eruption) and both comparison groups. There were no significant differences in genotype spread in individuals with MGPE (Table 5), unlike CG II, but there was a tendency to decrease the frequency of the AA genotype and increase the frequency of the heterozygous variant AG in the CYP19A1 gene gene (dominant and over-dominant models of inheritance, respectively) as well as increasing the frequency of the heterozygous variant of the RANKL gene (over-dominant inheritance model) in the main group. Similarly, there were no significant differences in the distribution of genotypes between MGPE and CGI groups.

In contrast to premature eruption, significant delays $(\mathrm{p}<0.05)$ were determined by comparing with the CGI: multiplicative model (Table 6) for the RANKL [rs9594759] gene and over-dominant model (Table 7) for the IL10 [rs1800896] gene when compared with the CGI. In patients with MGDE, in contrast to persons with CGII, the frequency of the heterozygous variant in IL 10 [rs1800896] gene were observed to decrease. Moreover, the mathematical 
Table 5. Distribution of polymorphic variants in CYP19A1 genes: A > G [rs2414096] and RANKL: C> T [rs9594759] in MGPE and CG II individuals.

\begin{tabular}{|c|c|c|c|c|c|}
\hline \multirow[b]{2}{*}{ Gene } & \multirow[b]{2}{*}{ Genotypes } & \multicolumn{4}{|c|}{ Results of statistical analysis } \\
\hline & & $\begin{array}{c}\mathrm{X}^{2} \text { (with Yates } \\
\text { correction)) }\end{array}$ & OR & $95 \% \mathrm{Cl}$ & $\mathbf{P}$ \\
\hline \multirow{16}{*}{$\begin{array}{c}\text { CYP19A1: A>G } \\
\text { [rs2414096] }\end{array}$} & \multicolumn{5}{|c|}{ Additive model } \\
\hline & AA & & 0.210 & $0.046-0.959$ & \multirow{3}{*}{0.164} \\
\hline & AG & 3.611 & 4.875 & $1.162-20.452$ & \\
\hline & GG & & 0.633 & $0.052-7.670$ & \\
\hline & \multicolumn{5}{|c|}{ Recessive model } \\
\hline & $\mathrm{AA}+\mathrm{AG}$ & 0.061 & 1.579 & $0.130-19.123$ & \multirow[t]{2}{*}{0.805} \\
\hline & & & & $0.052-7.670$ & \\
\hline & \multicolumn{5}{|c|}{ Dominant model } \\
\hline & $\mathrm{AA}$ & 3054 & 0.210 & $0.046-0.959$ & \multirow{2}{*}{0.081} \\
\hline & $\mathrm{AG}+\mathrm{GG}$ & 3.054 & 4.767 & $1.043-21.787$ & \\
\hline & \multicolumn{5}{|c|}{ Over-dominant model } \\
\hline & $A A+G G$ & & 0.205 & $0.049-0.861$ & \multirow{2}{*}{0.058} \\
\hline & AG & 3.605 & 4.875 & $1.162-20.452$ & \\
\hline & \multicolumn{5}{|c|}{ Multiplicative model } \\
\hline & $A$ & \multirow{2}{*}{1.836} & 0.514 & $0.195-1.353$ & \multirow{2}{*}{0.175} \\
\hline & G & & 1.944 & $0.739-5.116$ & \\
\hline \multirow{16}{*}{$\begin{array}{l}\text { RANKL: C>T } \\
\text { [rs9594759] }\end{array}$} & \multicolumn{5}{|c|}{ Additive model } \\
\hline & $\mathrm{CC}$ & & 0.833 & $0.191-3.644$ & \\
\hline & CT & 3.595 & 4.167 & $1.042-16.661$ & 0.166 \\
\hline & TT & & 0.190 & 0.034-1.059 & \\
\hline & \multicolumn{5}{|c|}{ Recessive model } \\
\hline & $\mathrm{CC}+\mathrm{CT}$ & & 5.250 & $0.945-29.181$ & \multirow{2}{*}{0.101} \\
\hline & TT & 2.685 & 0.190 & $0.034-1.059$ & \\
\hline & \multicolumn{5}{|c|}{ Dominant model } \\
\hline & CC & & 0.833 & $0.191-3.644$ & \multirow{2}{*}{0.896} \\
\hline & $\mathrm{CT}+\mathrm{TT}$ & $0.01 /$ & 1.200 & $0.274-5.248$ & \\
\hline & \multicolumn{5}{|c|}{ Over-dominant model } \\
\hline & $\mathrm{CC}+\mathrm{TT}$ & \multirow{2}{*}{2.989} & 0.240 & $0.060-0.960$ & \multirow{2}{*}{0.084} \\
\hline & $\mathrm{CT}$ & & 4.167 & $1.042-16.661$ & \\
\hline & \multicolumn{5}{|c|}{ Multiplicative model } \\
\hline & $\mathrm{C}$ & \multirow{2}{*}{1.304} & 1.714 & $0.678-4.336$ & \multirow{2}{*}{0.253} \\
\hline & $\mathrm{T}$ & & 0.583 & $0.231-1.476$ & \\
\hline
\end{tabular}

calculation showed that the proportion of persons with heterozygous variants was significantly reduced. Thus, individuals with macrosomia at birth had a significantly lower risk of developing delayed eruption, risk decreased by almost factor 6 , in case of presence of a heterozygous variant of the IL 10 gene.

The obtained results indicated that polymorphic variants of the IL-10 and RANKL genes modulated the growing risk of delayed eruption, starting in the prenatal period, in case of fetal macrosomia formation, which is associated with the features of CYP19A1 and ESR1genes polymorphism.

We have strongly confirmed the modifying effect of the RANKL [rs9594759] gene variant, when comparing individuals with MGPE and MGDE. Marked significant difference (Table 8 ) in the frequency of the TT genotype spread in the RANKL gene needs particular attention. In a cross-group comparison, we found (Table 3) that the prevalence of TT genotype was significantly lower in individuals with MGPE (12.50\%) and significantly higher in individuals with MGDE (48\%). That is, the recessive model of inheritance was significant. Therefore, in individuals born macrosomic, the term of tooth eruption depends on the variant of the RANKL [rs9594759] gene, and the process itself occurs from the prenatal period.

In general, we identified several significant models (multiplicative and additive) for this polymorphism, indicating its important role in tooth eruption terms in macrosomic-at-birth individuals, but not in individuals born with normal body weight. The modifying effect in this intergroup comparison was also found for the CYP19A1 $(A>G)$ [rs2414096] gene. The frequency of heterozygous variants was in $75 \%$ of those with MGPE, compared with $37.50 \%$ for MDDE, i. e., the risk of premature eruption was increased by factor 5 , and the over-dominant model of inheritance was significant. 
Table 6. Distribution of polymorphic variants according to the RANKL gene: C>T [rs9594759] in individuals of MGDE and CG I.

\begin{tabular}{|c|c|c|c|c|c|}
\hline \multirow{2}{*}{ Gene } & \multirow{2}{*}{ Genotypes } & \multicolumn{4}{|c|}{ Results of statistical analysis } \\
\hline & & $\mathrm{X}^{2}$ (with Yates correction) & OR & $95 \% \mathrm{Cl}$ & $\mathbf{p}$ \\
\hline \multirow{12}{*}{$\begin{array}{l}\text { RANKL: C>T } \\
\text { [rs9594759] }\end{array}$} & \multicolumn{5}{|c|}{ Additive model } \\
\hline & $\mathrm{CC}$ & & 0.369 & $0.117-1.165$ & \\
\hline & $\mathrm{CT}$ & 4.137 & 0.837 & $0.336-2.082$ & 0.126 \\
\hline & $\mathrm{TT}$ & & 2.658 & $1.073-6.585$ & \\
\hline & \multicolumn{5}{|c|}{ Recessive model } \\
\hline & $\begin{array}{c}\mathrm{CC}+\mathrm{CT} \\
\mathrm{TT}\end{array}$ & 3.655 & $\begin{array}{l}0.376 \\
2.658\end{array}$ & $\begin{array}{l}0.152-0.932 \\
1.073-6.585\end{array}$ & 0.056 \\
\hline & \multicolumn{5}{|c|}{ Dominant model } \\
\hline & $\begin{array}{c}\mathrm{CC} \\
\mathrm{CT}+\mathrm{TT}\end{array}$ & 2.262 & $\begin{array}{l}0.369 \\
2.707\end{array}$ & $\begin{array}{l}0.117-1.165 \\
0.858-8.539\end{array}$ & 0.133 \\
\hline & \multicolumn{5}{|c|}{ Over-dominant model } \\
\hline & $\begin{array}{c}\mathrm{CC}+\mathrm{TT} \\
\mathrm{CT}\end{array}$ & 0.024 & $\begin{array}{l}1.195 \\
0.837\end{array}$ & $\begin{array}{l}0.480-2.976 \\
0.336-2.082\end{array}$ & 0.877 \\
\hline & \multicolumn{5}{|c|}{ Multiplicative model } \\
\hline & $\begin{array}{l}\mathrm{C} \\
\mathrm{T}\end{array}$ & 6.440 & $\begin{array}{l}0.437 \\
2.290\end{array}$ & $\begin{array}{l}0.228-0.836 \\
1.196-4.386\end{array}$ & 0.011 \\
\hline
\end{tabular}

Table 7. The distribution of polymorphic variants by the gene IL 10 [rs1800896] in MGDE and GP II.

\begin{tabular}{|c|c|c|c|c|c|}
\hline \multirow{2}{*}{ Gene } & \multirow{2}{*}{ Genotypes } & \multicolumn{4}{|c|}{ Results of statistical analysis } \\
\hline & & $\mathrm{X}^{2}$ (with Yates correction) & OR & $95 \% \mathrm{Cl}$ & $\mathbf{p}$ \\
\hline \multirow{16}{*}{$\begin{array}{c}\text { IL } 10-1082 \\
\text { G>A } \\
\text { [rs1800896] }\end{array}$} & \multicolumn{5}{|c|}{ Additive model } \\
\hline & GG & & 3.300 & $0.876-12.426$ & \multirow{3}{*}{0.089} \\
\hline & GA & 4.840 & 0.171 & $0.045-0.658$ & \\
\hline & $\mathrm{AA}$ & & 4.471 & $0.454-44.013$ & \\
\hline & \multicolumn{5}{|c|}{ Recessive model } \\
\hline & $\mathrm{GG}+\mathrm{GA}$ & \multirow{2}{*}{0.804} & 0.224 & $0.023-2.202$ & \multirow{2}{*}{0.370} \\
\hline & $\mathrm{AA}$ & & 4.471 & $0.454-44.013$ & \\
\hline & \multicolumn{5}{|c|}{ Dominant model } \\
\hline & GG & \multirow{2}{*}{2.179} & 3.300 & $0.876-12.426$ & \multirow{2}{*}{0.140} \\
\hline & $\mathrm{GA}+\mathrm{AA}$ & & 0.303 & $0.080-1.141$ & \\
\hline & \multicolumn{5}{|c|}{ Over-dominant model } \\
\hline & $\mathrm{GG}+\mathrm{AA}$ & \multirow{2}{*}{5.476} & 5.833 & $1.519-22.406$ & \multirow{2}{*}{0.019} \\
\hline & GA & & 0.171 & $0.045-0.658$ & \\
\hline & \multicolumn{5}{|c|}{ Multiplicative model } \\
\hline & G & \multirow[b]{2}{*}{0.392} & 1.333 & $0.542-3.283$ & \multirow[b]{2}{*}{0.531} \\
\hline & A & & 0.750 & 0.305-1.847 & \\
\hline
\end{tabular}

Discussing the obtained results, we should pay attention to the fact that, according to some scientists, the minor allele (C) of RANKL rs9594759 gene may be associated with an increase in bone mineral density [31]. At the same time, it is known that homozygosity in the minor allele RANKL rs9594759 may also be associated with a low density of the cortical layer of bone tissue, which is explained by impaired muscle function and inability to redistribute a considerable degree of stress to bone tissue [32].

While analyzing obtained results as to deviations from the mean regional terms of deciduous teeth eruption, we found out that RANKL gene "worked" in macrosomic-at-birth individuals in two directions, depending on the genotype.

Studies concerning rats [33] showed that the anti-inflammatory cytokine IL-10 affected the tooth eruption processes. By increasing the expression of osteoprotegerin (OPG), it inhibits the resorption of the alveolar process, which is a prerequisite for the process of tooth eruption. At the same time, IL-10 decreases the expression of RANKL and colonstimulating factor-1 (CSF1). In our study, where we investigated the association between the change in the tooth eruption terms and fetal macrosomia, we also found a negative association of the heterozygous vari- 
Table 8. Comparison of the frequency distribution of polymorphic variants in CYP19A1 genes: A> G [rs2414096] and RANKL: C> T [rs9594759] for MGDE T and MGPE.

\begin{tabular}{|c|c|c|c|c|c|}
\hline \multirow{2}{*}{ Gene } & \multirow{2}{*}{ Genotypes } & \multicolumn{4}{|c|}{ Results of statistical analysis } \\
\hline & & $\mathrm{X}^{2}$ (with Yates correction) & OR & $95 \% \mathrm{Cl}$ & p \\
\hline \multirow{15}{*}{$\begin{array}{l}\text { CYP19A1: A>G } \\
\text { [rs2414096] }\end{array}$} & \multicolumn{5}{|c|}{ Additive model } \\
\hline & AA & & 1.784 & $0.385-8.267$ & \multirow{3}{*}{0.132} \\
\hline & AG & 4.053 & 0.200 & $0.049-0.812$ & \\
\hline & GG & & 7.500 & $0.835-67.350$ & \\
\hline & \multicolumn{5}{|c|}{ Recessive model } \\
\hline & $\begin{array}{c}A A+A G \\
G G\end{array}$ & 2.634 & $\begin{array}{l}0.133 \\
7.500\end{array}$ & $\begin{array}{c}0.015-1.197 \\
0.835-67.350\end{array}$ & 0.105 \\
\hline & \multicolumn{5}{|c|}{ Dominant model } \\
\hline & AA & \multirow{2}{*}{0.139} & 1.784 & $0.385-8.267$ & \multirow{2}{*}{0.709} \\
\hline & $\mathrm{AG}+\mathrm{GG}$ & & 0.560 & $0.121-2.597$ & \\
\hline & \multicolumn{5}{|c|}{ Over-dominant model } \\
\hline & $A A+G G$ & \multirow{2}{*}{4.014} & 5.000 & $1.231-20.301$ & \multirow{2}{*}{0.045} \\
\hline & AG & & 0.200 & $0.049-0.812$ & \\
\hline & \multicolumn{5}{|c|}{ Multiplicative model } \\
\hline & $A$ & \multirow{2}{*}{0.534} & 0.716 & $0.291-1.759$ & \multirow{2}{*}{0.465} \\
\hline & G & & 1.398 & $0.569-3.434$ & \\
\hline \multirow{16}{*}{$\begin{array}{l}\text { RANKL: C>T } \\
\text { [rs9594759] }\end{array}$} & \multicolumn{5}{|c|}{ Additive model } \\
\hline & $\mathrm{CC}$ & & 0.571 & $0.120-2.711$ & \multirow{3}{*}{0.159} \\
\hline & $\mathrm{CT}$ & 3.673 & 0.338 & $0.092-1.239$ & \\
\hline & TT & & 6.462 & $1.208-34.551$ & \\
\hline & \multicolumn{5}{|c|}{ Recessive model } \\
\hline & $\mathrm{CC}+\mathrm{CT}$ & \multirow{2}{*}{4.003} & 0.155 & $0.029-0.828$ & \multirow{2}{*}{0.045} \\
\hline & TT & & 6.462 & $1.208-34.551$ & \\
\hline & \multicolumn{5}{|c|}{ Dominant model } \\
\hline & CC & \multirow{2}{*}{0.093} & 0.571 & $0.120-2.711$ & \multirow{2}{*}{0.760} \\
\hline & $\mathrm{CT}+\mathrm{TT}$ & & 1.750 & $0.369-8.302$ & \\
\hline & \multicolumn{5}{|c|}{ Over-dominant model } \\
\hline & $\mathrm{CC}+\mathrm{TT}$ & \multirow{2}{*}{1.793} & 2.963 & $0.807-10.878$ & \multirow{2}{*}{0.181} \\
\hline & $\mathrm{CT}$ & & 0.338 & $0.092-1.239$ & \\
\hline & & Multip & model & & \\
\hline & $C$ & 3048 & 0.401 & $0.161-0.997$ & 0047 \\
\hline & $\mathrm{T}$ & 3.948 & 2.496 & $1.003-6.208$ & 0.047 \\
\hline
\end{tabular}

ant of the IL-10 gene with delayed tooth eruption. Thus, our attempt to analyze the obtained data on the peculiarities of the genetic component of bone metabolism in individuals born macrosomic and to relate them to the information about the tooth eruption timing in the studied contingent has yielded positive results. In clinical practice, very often, the combination of general and local factors of influence almost does not leave the child the opportunity to have healthy teeth. The results we have obtained can be used to predict the terms of tooth eruption in individuals born macrosomic and help to guide the start of preventive procedures and improve the dental health of each child, even if the situation is difficult to change.

\section{CONCLUSIONS}

1. The presence of the allele $\mathrm{G}$ in the CYP19A1 [rs2414096] gene and the presence of the allele $-351 \mathrm{~A}$ in the ESR 1 gene [rs9340799] were found to be risk factors for the fetal macrosomia formation.

2. The study identified an association of variants in RANKL gene [rs9594759], a multiplicative model of inheritance, and in IL-10 gene [rs1800896], an over-dominant model of inheritance, with an increased risk of delayed deciduous tooth eruption.

3. The macrosomic-at-birth individuals with premature eruption showed a tendency to decrease the frequency of the AA genotype in the CYP19A1 gene (dominant model of inheritance) and a tendency to increase the frequency of the heterozygous variant in the RANKL gene (over-dominant model of inheritance).

4. Variants of the RANKL and IL-10 genes as well as the CYP19A1 gene [rs2414096] have a multidirectional modifying effect on the timing of teeth eruption in macrosomic-at-birth individuals, and further analysis 
of intergenic interactions will help to create a molecular profile of abnormalities.

5. The practical implementation of the findings into clinical practice is necessary to plan preventive procedures and develop a number of new ways to maintain the child's dental health.

\section{REFERENCES}

1. Martin JA, Hamilton BE, Sutton PD, et al. Births: final data for 2004. National Vital Statistics Reports. 2006; 55(1): 1-101.

2. Sajjadian N, Shajari H, Jahadi R, et al. Relationship between birthweight and time of first deciduous tooth eruption in 143 consecutively born infants. Pediatr Neonatol. 2010; 51(4): 235-237. doi: 10.1016/S18759572(10)60044-7.

3. Garmash 0, Likhacheva N, Khizhnyak V. et al. Differences in the time of primary teeth eruption in children with born prematurely, intrauterine fetal hypotrophy and intauterine growth retardation syndrome diagnosis. Nauchnye vedomosty Bel GUSery`ya Medy 'cy' na. Farmacy'ya. 2013; 11(154) (22/1):43-47. (Ru).

4. Rãducanu AM., Feraru VI. Delayed eruption - Case study. OHDMBSC 2007;6 (4): 58-65.

5. Miller 0. Characteristics of the eruption time of deciduous teeth in children of early age living in a large industrial center (on the example of Krasnoyarsksity) (Dis. ... cand. med science.). 2012; Krasnoyarsk State Medical University named after Professor V.F. Voino-Yasenetsky (Ru).

6. Suri L, Gagari E, Vastardis E. Delayed tooth eruption: Pathogenesis, diagnosis, and treatment. A literature review. American Journal of Orthodontics and Dentofacial Orthopedics. 2004; 126:432-445.

7. Garmash 0. Dependence of Deciduous Tooth Eruption Terms and Tooth Growth Rate on the Weight-Height Index at Birth in Macrosomic Children over the First Year of Life. Acta Medica (Hradec Kralove). 2019;62(2):6268. doi: 10.14712/18059694.2019.48.

8. Ntani G, Day PF, Baird J, et al. Maternal and early life factors of tooth emergence patterns and number of teeth at one and two years of age. J Dev Orig Health Dis. 2015 Aug; 6(4): 299-307. doi: 10.1017/ S2040174415001130

9. Bastos IL, Peres MA, Peres KG, et all. Infant growth, development and tooth emergence patterns: A longitudinal study from birth to 6 years of age. Arch Oral Biol. 2007 Jun;52(6):598-606.

10. Sajjadian 1, Shajari H, Jahadi R, et all. Relationship between birth weight and time of first deciduous tooth eruption in 143 consecutively born infants. PediatrNeonatol.2010;51(4):235-7. doi:10.1016/S1875-9572(10)60044-7.

11. Khuraseva $A B$. Adaptation of newborns and their development in the first year of life depending on body mass at the birth. Nauchnye vedomosty` Bel GU Sery ya Medy'cy'na. Farmacy’ya. 2014; 4 (175) (25):102-105. [Ru].

12. Garmash 0 . An eruption pattern of deciduous teeth in children born with fetal macrosomia during the first year of life. Georgian Medical News 2017; 2(263):14-23.

13. Garmash OV. Dentists view on fetal macrosomia. Svit medytsyny ta biolohii. 2018; 4 (66):40-46.

14. Zemaitiene M, Grigalauskiene R, Andruskeviciene V, et all. Dental caries risk indicators in early childhood and their association with caries polarization in adolescence: a crosssectional study. BMC Oral Health (2017) 17:2 DOl 10.1186/s12903-016-0234-8.

15. Gozes I, Van Dijck A, Hacohen-Kleiman G, et all. Premature primary tooth eruption in cognitive/motor-delayed ADNP-mutated children. Transl Psychiatry. 2017 Feb 21;7(2):e1043. doi: 10.1038/tp.2017.27.
16. Fatemifar G, Hoggart CJ, Paternoster L,et all. Genome-wide association study of primary tooth eruption identifies pleiotropic loci associated with height and craniofacial distances Hum Mol Genet. 2013 Sep 15; 22(18): 3807-3817.

17. Dursun F, Ceylaner S, Novel A. Homozygous CYP19A1 Gene Mutation: Aromatase Deficiency Mimicking Congenital Adrenal Hyperplasia in an Infant without Obvious Maternal Virilisation J Clin Res Pediatr Endocrinol 2019;11(2):196-201.

18. Janner M, Flück CE, Mullis PE. Impact of estrogen replacement throughout childhood on growth, pituitary-gonadal axis and bone in a 46, XX patient with CYP19A1 deficiency. Horm Res Paediatr 2012;78:261-268.

19. Eriksson AL, Perry JRB, Coviello AD, et all. Genetic Determinants of Circulating Estrogen Levels and Evidence of a Causal Effect of Estradiol on Bone Density in Men. J Clin Endocrinol Metab, March 2018; 103(3):991-1004.

20. Kamiński A, Bogacz A, Górska-Paukszta M, et all. Correlation of rs749292 and rs700518 polymorphisms in thearomatase gene (CYP19A1) with osteoporosis in postmenopausal Polish women. Adv Clin Exp Med. 2019;28(8) :1-5.

21. Hong X, Hsu YH, Terwedow H, et all. CYP19A1 polymorphisms are associated with bone mineral density in Chinese men. Hum Genet. 2007 May;121(3-4):491-500.

22. Garmash 0.V. Obgruntuvannia dotsilnosti doslidzhennia odnonukleotydnoho polimorfizmu $v$ heni aromatazy yak mozhlyvoho markeru ryzyku rozvytku rannoho dytiachoho kariiesu u osib, yaki narodylys iz makrosomiieiu. «Modern aspects of the molecularbiochemical studies and laboratory screening in the clinical and experimental medicine» 11-12 April 2019; 15-16 (UA).

23. Villa A., Guerrini MM., Cassani B, et all. Infantile malignant, autosomal recessive osteopetrosis: the rich and the poor. Calcif Tissue Int 2009;84(1):1-12.

24. Multiple Genetic Loci for Bone Mineral Density and Fractures. Styrkarsdottir U, Halldorsson BV, Gretarsdottir S, et al N Engl J Med 2008;358:2355-2365. doi: 10.1056/NEJMoa0801197

25. Amarasekara DS, Yun H, KimS, et al. Regulation of Osteoclast Differentiation by Cytokine Networks. Immune Netw. 2018 Feb; 18(1): e8. doi: 10.4110/in.2018.18.e8.

26. Ruscitti P, Cipriani P, Carubbi F, et al. The role of IL-1 $\beta$ in the bone loss during rheumatic diseases. Mediators Inflamm. 2015;2015:782382.

27. Feng W, Liu H, Luo T, et al. Combination of IL-6 and sIL-6R differentially regulate varying levels of RANKL-induced osteoclastogenesis through NF-kB, ERK and JNK signaling pathways. Sci Rep. 2017 Jan 27; 7:41411.

28. Wang Z, Yang Y, He M, et al. Association Between Interleukin- 6 Gene Polymorphisms and Bone Mineral Density: A Meta-Analysis Genet Test Mol Biomarkers. 2013 Dec; 17(12): 898-909.doi: 10.1089/ gtmb.2013.0223.

29. Moffett SP, Zmuda JM, Cauley JA, et al. Association of the G-174C variant in the interleukin- 6 promoter region with bone loss and fracture risk in older women. J Bone Miner Res. 2004 0ct; 19(10):1612-8.

30. The pathophysiologic roles of interleukin-6 in human disease (An edited summary of a Clinical Staff Conference held on 13 March 1996 at the National Institutes of Health, Bethesda, MD). Ann Intern Med 1998;128:127-37.

31. Roshandel D, Holliday KL, Pye SR, et al. Genetic variation in the RANKL/ RANK/OPG signaling pathway is associated with bone turnover and bone mineral density in men.J Bone Miner Res. 2010 Aug;25(8):1830-8. doi: 10.1002/jbmr.78. 
32. Varley I, Hughes DC, Greeves JP, et al. SNPs in the vicinity of P2X7R, RANK/ RANKL/OPG and Wnt Signalling Pathways and their Association with Bone Phenotypes in Academy Footballers. Bone. 2018 Mar;108:179-185. doi: 10.1016/j.bone.2018.01.007.

33. Liu D, Yao S, Wise GE. Effect of interleukin-10 on gene expression of osteoclastogenic regulatory molecules in the rat dental follicle. Eur J Oral Sci. 2006 Feb;114(1):42-9.

The study is a fragment of the research project "Character, structure and treatment of main dental diseases", state registration No. $0116 U 004975$.

\section{ORCID and contributionship:}

Olga V. Garmash - 0000-0001-7935-9371 A, B, C, D, F

Zoia I. Rossokha - 0000-0002-4767-7364 ${ }^{\mathrm{B}}$

Nataliya G. Gorovenko - 0000-0003-4227-7166 ${ }^{\mathrm{E}}$

\section{Conflicts of interest:}

Authors declare no conflict of interest.

\section{CORRESPONDING AUTHOR Olga V. Garmash Apt 51, Heroiv Pratsi St., 4-V 61168, Kharkiv, Ukraine tel: +380666949665 e-mail: o.v.garmash@gmail.com}

Received: 15.04 .2019

Accepted: 11.11.2019

A - Work concept and design, B - Data collection and analysis, C - Responsibility for statistical analysis, D-Writing the article, $\mathbf{E}$-Critical review, $\mathbf{F}$ - Final approval of the article 